\title{
White voices, black silences and invisibilities in the XIX century travel narratives*
}

Fecha de recepción: 26 de mayo de 2014

Fecha de aprobación: 30 de diciembre de 2014

\section{Abstract}

The manipulation of the image of Afro-descendants in XIX century travel narratives accounts for certain ideological practices. This essay does not only reflect on the representation of the Other. It also seeks to explore the ambivalence that occurs in the contact zones as well as discursive strategies used to depict Otherness. The recurrent portrayals of these populations turn out to be revealing because of all the ideas, attitudes and prejudice they convey. How do these rhetorical mechanisms come into play and what tensions do they inscribe? We will attempt to reflect on these issues through the exploration and comparison of travel accounts written by four travelers: Alexander Von Humboldt (1769-1859), Flora Tristán (1803-1844), Charles Darwin (18091882) and Miguel Cané (1851-1905).

Keywords: Ambivalence; Travel literature; Post-colonialism; Identity; Representation; Race; Diaspora.

* Artículo de reflexión como parte del proyecto de tesis doctoral

Citar: Díaz, D. (enero-junio de 2015). White voices, black silences and invisibilities in the XIX century travel narratives. La Palabra (26), páginas $17-29$

\section{Dorismel Díaz}

Western University, Canadá

ddazpere@uwo.ca

Candidato al doctorado en el programa de Estudios Hispanos/Migración y Estudios Étnicos. Asistente de enseñanza. Western University, London, Ontario, Canadá. 


\section{la palabra}

\section{Voces blancas, negros silencios e invisibilidades en relatos de viajes del siglo XIX}

\section{Resumen}

La manipulación de la imagen del afrodescendiente en la narrativa de viajes del siglo XIX, da cuenta de la puesta en marcha de ciertos proyectos ideológicos. Este ensayo no se detiene únicamente en la representación del Otro. También busca explorar la ambivalencia en las zonas de contacto, así como también las estrategias discursivas empleadas para describir a la Otredad. Estas recurrentes descripciones revelan ideas, actitudes y prejuicios imbuidos en esos relatos. ¿Cómo entran en juego estos mecanismos retóricos y qué tensiones inscriben? A través de la exploración y el análisis de las obras de cuatro viajeros: Alexander Von Humboldt (1769-1859), Flora Tristán (1803-1844), Carlos Darwin (1809-1882) y Miguel Cané (1851-1905), se hará un intento de reflexionar sobre el particular.

Palabras clave: Ambivalencia, literatura de viajes, postcolonialismo, identidad, representación, raza, Diáspora.

\section{Voix blanches, noirs silencieux et invisibilités dans des récits de voyages du XIXème siècle}

\section{Résumé}

La manipulation de l'image de l'afrodescendant dans la narrative des voyages du XIXème siècle, rend compte de la mise en œuvre de certains projets idéologiques. Cet essai ne s'arrête pas seulement dans la représentation de l'Autre. Il cherche aussi à explorer l'ambivalence dans les zones de contact, ainsi que les stratégies discursives employées pour décrire l'Altérité. Ces descriptions récurrentes révèlent des idées, des attitudes et des préjugés imbus dans ces récits. Comment ces mécanismes rhétoriques, entrent-ils en jeu et quelles tensions inscrivent-ils? À travers l'exploration et l'analyse des œuvres de quatre voyageurs : Alexander Von Humboldt (1769-1859), Flora Tristán (1803-1844), Carlos Darwin (1809-1882) et Miguel Cané (1851-1905), on essayera de réfléchir sur le sujet.

Mots clés: ambivalence, littérature de voyages, postcolonialisme, identité, représentation, race, Diaspora. 
In $19^{\text {th }}$ century literature, depictions of blacks and indigenous peoples were often romanticized and manipulated. One of the least studied areas of literature that frequently portrayed this manipulation is the genre of travel books. The growing interest in the depiction of "Otherness" in travel accounts coincided with a deep felt desire to support humanitarian values by helping marginalized and oppressed people who were still affected by the burden of slavery in certain parts of the world. In this study we will focus on the depiction of transatlantic black communities both in the Americas and Africa, where many of these memorialized expeditions took place. Whether for political, religious or scientific reasons, some of these journeys were taken mostly by male Europeans and attracted popular attention. As Thompson argues: "Explorers came to be regarded as emblematic figures, ideal types of imperial masculinity who embodied the highest ideals of science and Christian civilization" (Thompson, 2011, p.53). Some travelers used the experience of travel as a means to fight against social injustice as well as foster equal rights for all human beings. To a certain extent, some of the travelers we study failed to be aware of this and, instead, articulated a dynamic of representation which reveals similarities with the representation of the "Other" in colonial discourses.

It is useful to remember that America as a whole continent was the product and construct of colonialism. Mary Louise Pratt in her book Travel Writing and Transculturation convincingly argues that Spanish American independence movements were of such great interest to the French and British empires that an entirely new genre, travel narrative, was developed to provide information about these new nations to the European metropolis. These writers rewrote and reinvented America in ways that suited the ideological, political and economic projects of their empires. As a matter of fact, she purports to highlight the significance of this discourse by discussing the phenomenon of "contact zones", which, from her perspective, are defined as:

Spaces of colonial encounters, the space in which people geographically and historically separated come into contact with each other and establish conditions of coercion, radical inequality and intractable conflict. This definition includes copresence, interaction, interlocking understandings and practices often within radically asymmetrical relations of power (Pratt, 1992, p.8).

Another concept she suggests that is key to the purpose of this study is the "anti-conquest narrative", which refers to strategies of representation whereby travelers "seek to secure their innocence at the same moment as they assert European hegemony" (Pratt, 1992, p.7). A last concept is "auto ethnographic expression" in which subjects undertake to "represent themselves in ways that engage with the colonizer's own terms" (p.7). These concepts all serve to raise important questions: To what extent has the discourse of representation in travel accounts been tinged by the traveler's prejudice and preconceived assumptions? Can travel narratives be considered testimonial sources to understand social and cultural processes of the people of African origin? Do travelers establish themselves as cultural mediators who can bridge a cultural gap? Can the experience of journey and contact with the ethnic "Other" bring about changes in the traveler's views?

It can be argued that, in these narratives, lack of "proper" clothing, representation of cultural difference and the spaces bodies are allowed to occupy, are textual markers for inclusion and exclusion as we will see further on. As Phillion has noted, Clifford emphasizes the fact that early travel writing has come to be seen as the beginning or the roots of ethnographic work (Phillion, 2006, p. 5). As a matter of fact, one of the early allusions to American black communities in Columbus' accounts is tied to the colonial ambitions and imaginary constructions of these people. Humboldt relates that,

The island of Hayti was sometimes attacked by a race of black men, gente negra, who lived more to the south or south-west. He hoped to visit them in his third voyage, because those black men possessed a metal guanine 
of which the admiral had procured some pieces in his second voyage (Humboldt, 1852, p.133).

Travel writers usually became instruments of cultural dominance as they positioned themselves as intellectual authorities over alterity because of their power to define, interpret and represent "Otherness". In this very attempt at defining and (mis) representing the ethnic "Other", they distanced themselves from an "uncivilized" world constituted by drunkenness, idolatry, cannibalism or other "barbaric" behaviors. Edward Said's work on Orientalism seems to suggest that postcolonial travel writing continues to incorporate the same attitudes expressed in the writings of their predecessors (Said, 1978, p.177).

It is important to clarify that representation actually means the textual depiction and portrayal of all the peoples of the African Diaspora or the constructed classifications they were referred to at that moment, and later on, (such as blacks, negroes, mulattos, zambos, afro-latinos, afro-hispanics, morenos) by the travelers who, to a certain extent, used the power granted to them by the writing of their accounts. In his book titled Lettered City, Angel Rama discussed the relationship between power and writing and how both were articulated in the colonial society (Rama, 1984, p.4), said assumptions could be applied to postcolonial society as well.
To complement the above, Thompson argues that, travel writing was a cultural form steeped in imperialist attitudes and imagery (Thompson, 2011, p.137). A careful and close reading of such works demonstrates that an inconsistent, incoherent and contradictory approach lies beneath the rhetoric with regard to the way in which the people of the "periphery" were portrayed.

The intention here is to analyze transatlantic perspectives delineated in the writings of four authors: Flora Tristán, Alexander Von Humboldt, Charles Darwin and Miguel Cané. The first text we will study, PeregrinacionesdeunaParia [Pariab'sPilgrimage], waswritten in 1833 by Flora Tristán (18031844). For the purpose of this study, her journey has a specific significance. The choice of a female traveler is revealing because it provides insight into what writing was for a woman when writing was still patriarchal and gender biased. This narrative allows for an analysis and comparison between male and female discourse in relation to the representation of the African experience.

Flora Celestine Henriette Tristán Moscoso was born on April 7, 1803. Her mother had returned to France from Spain where she had been a refugee during the French Revolution. There she met and married Mariano Tristán, a Peruvian man from a distinguished family and a colonel in the Spa- nish Army. The young Simon Bolivar, future leader of the struggle for Latin American independence, knew the Tristáns in Spain, and visited them in their home. Don Mariano's younger brother, Don Pío de Tristán, who would eventually take part, with Bolívar, in the formation of the Republic of Perú, also influenced Flora's future (Tristán, 1833, p.13). Her travel accounts between France and Peru encompasses a set of transatlantic experiences which are imbued with strains of feminism, activism and even socialism. Perhaps, due to her being influenced by positivist theories, in Pariab's Pilgrimage, her depiction of the Indians, as well as Africans, is that of a "barbaric" people.

The next traveler of interest is a very well known scientific authority and public figure: the author of the Origin of Species, Charles Darwin. He was born to a prestigious family in Shrewsbury in 1809 and died in 1882. In one of his writings, inspired by his journeys on the Beagle, he outlined careful notes of his observations and theoretical speculations, not only about the flora and fauna but also insights into the native people who inhabited the coastline of South America. The Voyage of the Beagle (1831), Autobiography (1887), and Correspondences (1887-1903), are of interest for the purpose of this study because of their frequent references about the social situation of the black community. 
Miguel Cané (1851-1905). A Uruguayan-Argentine writer, journeyed through the countries of Venezuela, Pana$\mathrm{ma}$ and the United States of Colombia. As a journalist, politician and scholar, he began writing down his impressions about the geography, the culture and the people of these regions in En viaje [On Voyage] (1881-1882). In these descriptions he includes the traditions and customs of indigenous peoples, natives and blacks in these countries.

The last traveler is Alexander Von Humboldt (17691859). In his travel diaries, he accounts not only for his expeditions as a scientist but also for his humanitarian work. His Personal Narrative of Travels to the EquinoctialRegions of America (1799-1804) is of interest here. As an observer of "Otherness", he clearly demonstrates his enlightened ideas through anecdotal accounts of his encounters with the primarily black "bogas" or oarsmen who lived mainly in Cuba, Venezuela and Colombia.

The common thread or leitmotiv which pervades these writings is the ambiguity in the four authors' discursive lines by which blacks or "coloured" people are praised and, at the same time, debased. In other words, the strategies for the depiction of blacks fluctuated according to the ideological climate. At times, such depictions were flattering, benevolent or idealizing; however, at other moments, the references were vilifying, condemning or disturbing. These (mis) representations resulted in the molding of the meaningfulness of the peoples of African origin within the text. As Todorov has pointed out, tensions originated with the first encounters between the Europeans and the natives where the relations to the Other were not one dimensional but revolved around three axes: axiological, where there is a value judgment (the other is good or bad); a distancing level, where one imposes his own image upon the Other; and, the epistemic level, where one either knows or is ignorant of the Other's identity (Todorov, 1995, p.185). It is important to make sense of these works themselves as well as the silences or gaps that divide them. These pendulum dynamics in the aesthetics of representation are revealing because they allow not only for the detection, but also the exploration of the cultural discordances and tensions that result from the contact between the traveler and the locals.

\section{Smelly bodies / repulsive slavery}

Having briefly considered the biographies of the travelers, the ambiguous imaginary constructions of the "Others" in their texts will be examined. The complexity of these encounters also must be addressed. These travelers all seem to attempt to legitimize their own writing. It is interesting to notice that Flora Tristán resorts to a self-centered approach as she insists on the legitimacy of her writing, comparing it to the priesthood, an unlikely comparison for a woman of her time:

En el curso de la narración hablo a menudo de mí misma. Me pinto con mis dolores, mis pensamientos y mis afectos. (...) Todo escritor debe ser veraz. Si no se siente con el valor de hacerlo debe renunciar al sacerdocio que asume: el de instruir a sus semejantes. La utilidad de sus escritos resultará de las verdades que contengan. (Tristán, 2003, p.79).

The textual depiction of blacks in Pariab's Pilgrimage radiates between two levels: axiological and distancing levels. The author's first allusion to the black topic is in reference to the system of slavery. For her, slavery is in opposition to civilization and progress:

¿Existe acción más odiosa que la de esos hombres que en las selvas de América van a la caza de negros fugitivos para traerlos de nuevo bajo el látigo del amo? La esclavitud está abolida, se dirá, en la Europa civilizada (Tristán, 2003, p.77).

By claiming this, Flora constructs herself as part of a "civilized circle" taking on the role of the bearer of core values. In doing so, she distances herself while, at the same time, confers upon herself the right to moralize because she perceives herself as being from a so-called higher position in society. 
In her first account about blacks, she portrays them as almost naked, like the Noble Savage figure, and even feels proud when she compares her boat to the other wretched boats carrying blacks. (Tristán, 2003, p.108). When she reaches the village of La Praia and begins her direct contact with blacks, the axiological level is replaced by a scatological description revealing an ambiguous attitude:

Toda la población estaba en las calles (...) Entonces sentimos el olor de negro, que no puede compararse con nada, que da náuseas y persigue por todas partes. Se entra en una casa y al instante siente uno esa emanación fétida. Si uno se acerca a alguno de esos niños para ver sus juegos, tiene que alejarse rápidamente, ¡Tan repugnante es el olor que exhalan! Yo tengo los sentidos muy aguzados y el menor olor se me va a la cabeza o al estómago. Sentía un malestar tan insoportable que nos vimos obligados a precipitar la marcha para encontrarnos fuera del alcance de aquellas exhalaciones africanas. (Tristán, 2003, p.114-115).

This description goes hand in hand with the verbal treatment towards blacks portrayed in her writing. She considers them to be docile but, at the same time, they are wretched and despicable; she even attempted to physically assault one in order to get him to be obedient to her (p.32324). This ambivalent discourse contrasts with her views on sla- very when she visits the sugar plantations in Arequipa (Peru). She is horrified by the cruelty of the system and shows herself to be as an ambassador and supporter of liberal ideas.

La esclavitud ha excitado siempre mi indignación y sentí un gozo inefable cuando tuve noticia de la formación de esa santa Liga de Señoras inglesas que se abstenían del consumo de azúcar de las colonias occidentales (...) La esclavitud es una impiedad a los ojos de todas las religiones y participar en ella es renegar de sus creencias (p.404).

In addition, on the very same page, her paternalistic views regarding slavery contrast with her textual depictions of the blacks she sees on the sugar plantation.

$\mathrm{Al}$ pasar por una especie de granja donde trabajaban algunos negros, sonó el ángelus. Todos abandonaron su trabajo, cayeron de rodillas y postraron sus rostros contra la tierra. La fisonomía de aquellos esclavos era repugnante de bajeza y de perfidia. Su expresión era fría, cruel y desgraciada hasta en los niños. Traté de entablar conversación con algunos, pero no pude obtener sino un sí o un no pronunciados con sequedad e indiferencia (Tristán, 2003, p.515).

\section{The "bad", the "savage" and the "ugly"}

Similar to Tristán in the first pages of her book, Miguel Cané's narrative on blacks occupies a space of particular importance both in the axiolo- gical and distancing levels: they are not depicted as naked subjects but are cast in the text as people influenced by atavism, degradation and animalization as he encounters the "...negrillos en sus piraguas primitivas o nadando alrededor del buque como cetáceos..." (2005, p.34). Further on in the text, black women are compared to ants, horses, bulls, birds and orangutans and are attributed animalistic characteristics as they growl like certain beasts (2005, p.36-7). Interestingly, the peculiar repulsiveness that Tristán finds in them also exposed in Cané's narration, is accompanied by an aesthetic judgment when he describes a bamboula (dance accompanied by drums) performed by some blacks from the Caribbean. The construction and imposition of an aesthetic culture is almost as important and as necessary in the construction of "Otherness".

La bamboula las ha transfigurado. Gritan, gruñen, se estremecen y por momentos se cree que esas fieras van a tomarse a mordiscos. Es la bacanal más bestial que es posible idear, porque falta aquel elemento que purificaba hasta a las más inmundas orgías de las fiestas griegas: la belleza. No he visto nada más feo, más repulsivo que esos negros sudorosos: me daban la idea de orangutanes bramando de lascivia. (Cané, 2005, p.74).

When cultural practices are minimized and devalued, as seen here through their asso- 
ciation with the animalistic, the impure or immoral, it becomes a way of asserting and legitimizing practices of oppression within colonial and postcolonial contexts. According to the Western canon to which Cané must have ascribed, blacks are outside the traditional patterns of beauty. The "ugliness" of blacks is, therefore, intimately linked to their blackness. This representation holds threatening implications: the cultural difference exposed here is linked in the text to a source of danger since, according to Cané, "apareció el gremio terrible de los mulatos, zambos y cuarterones, herederos de los malos instintos de las dos razas que representan" (Cané, 2005, p.76).

The author does not hesitate to note, however, on the previous page, what he made known about "la repugnancia estética que me causaba la explotación del hombre por el hombre" (Cané, 2005, p.75). Not only does Cané depict blacks as inferior, but he suggests that, since they are devoid of the "positive" characteristics of his race, they become a social and cultural threat. Besides being considered as a threat, fear is another marker in his relationship with the African community as he relates that "No hay negro que no sea comunista, como no hay canónigo que no sea conservador. El día que suceda lo que se teme, habrá una invasión a las propiedades de los blancos que, reprimida o no, traerá segura- mente la ruina" (Cané, 2005, p.77).

In his treatment of blacks, Cané creates a space of "hygienization” just as Tristán did when referring to the lack of hygiene of black population. Aesthetic values as indicators of difference turn into aseptic parameters to measure the cultural patterns of the noncanonical culture. An episode that exemplifies this is when Cané is visiting Colon (Panama) where he notes that,

Me dirijo al mulatillo de cara canalla que está fabricando un whisky-cocktail y le pregunto con quién me entiendo para obtener cuarto. El infame zambo, sin quitarse el pucho de la jeta, me contesta, en inglés, a pesar de ser panameño, que arriba está la dueña y que con ella me entenderé. Fue en vano buscarla: una negra vieja, inmunda, casi desnuda, que me parecía esperar ansiosa la noche para enhorquetársele al palo de escoba, tuvo compasión de mí y me llevó a un cuarto (...) Como si un soplo hubiera animado el barro y formado con él cuerpos de mujeres, brotaron del suelo en un instante centenares de negras, mulatas, cuarteronas lívidas, descalzas en su mayor parte, ebrias, inmundas, que a su vez, atraídas por la fascinación del juego se agolpaban alrededor de las mesas, rechinaban los dientes cuando perdían y asaltaban a los marineros tambaleantes, pidiéndoles en un idioma que no era ni inglés, ni francés, ni español, ni nada conocido (...) ¡Esas mujeres, sobre todo esas mujeres, asquerosas arpías, negras y angulosas, esparciendo a su alrededor la mezcla de su olor ingénito y de un pacholí que hace dar vuelta al estómago!... ¡puah! (Cané, 2005, p.294).

These excerpts demonstrate how Cané textually represses the ethnic "Other" within his pages, and at the same time, portrays himself as an enemy of the oppressive system of slavery. From this point of view, he is resorting to the anti-conquest strategy, suggested by Pratt, in which the bourgeois seeks to secure their own innocence from imperial assertions, but at the same time enacts hegemony. Fear of the black collectivity is dispelled through apparently kind ideological positions such as the rejection of slavery and a betterment of the conditions of slaves.

\section{The "primitive" and the "civilized".}

By undertaking a careful discourse analysis of Charles Darwin's narrative, his work can be studied from both a technological and an aesthetic dimension. The appearance of Africans and afro descendants in his texts is framed by what would now be called a pseudo-scientific rhetoric since blacks and other races were supposed to be located on the lower levels of the evolutionary staircase. They are placed in the realm of savagery and animality. Darwin, as a liberalminded, and enlightened white 
European traveler, agreed with other scientists in setting up a limit between the social instincts of the "savages" and the subjectivity based on the moral principles of the civilized man. In The Descent of Man he states: "when a race reaches the maximum of physical development, it rises at the same time to the highest degree of energy and moral force". (Darwin, 1871, p.36).

Within Darwin's perspective, human societies are hierarchized, based on technology and on the nature of their social and political organization. An episode to exemplify this is when he describes an African man's post-house between the Colorado River and the city of Buenos Aires, in Argentina:

This posta was commanded by a Negro lieutenant, born in Africa [...] he had a little room for strangers, and a small corral for the horses, all made of sticks and reeds; he had also dug a ditch round his house as a defense in case of being attacked. This would, however, been of little avail, if the Indians had come [...] a short time before, a body of Indians had traveled past in the night, if they had been aware of the posta, our black friend and his four soldiers would assuredly have been slaughtered (Darwin, 1839, p. 68).

This description points out the minimalized and "primitive" aspect of a black individual's survival techniques as belonging to a "lower scale" society and, at the same time, serves to make room for legitimizing two ideologies; that is to say, Darwin's ideas on races and the promotion of a narrative of Western progress. David Spurr, in The Rhetoric of the Empire, emphatically states that, in order to justify the colonial enterprise, the ideology of colonization was always looking to classify or categorize natives according to their level of technical or political sophistication: "classification is indispensable to colonization ideology. It serves to demonstrate the fundamental justice of colonial enterprise by ranking native peoples according to their relative degree of technical and political sophistication from the European point of view" (Spurr, 1993, p.70).

As for the aesthetic dimension in Darwin, the good taste and the appreciation for the beautiful are absent in his idea of civilized communities: "judging from the hideous ornaments and the equally hideous music admired by most savages, it might be urged that their aesthetic faculty was not so highly developed as in certain animals" (Darwin, 1871, p.81). Interestingly, he does not hesitate in pointing out the contrast between the perception of physical beauty among blacks and the model of beauty in Europeans' eyes:

With respect to color, the Negroes rallied Mungo Park on the whiteness of his skin and the prominence of his nose, both of which they consider as "unsightly and unnatural conformations", $\mathrm{He}$, in return, praised the glossy jet of their skins and the lovely depression of their noses; this they said was "honeymouth", nevertheless they gave him food. The African Moors, also, "knitted their brows and seemed to shudder at the whiteness of his skin. On the Eastern coast the Negro boys, when they saw Burton, cried out, "Look at the white man, does he not look like a white ape?" On the western coast, as Mr. Winwood Reade informs me the Negroes admire a very black skin more than one of a lighter tint. But their horror of whiteness may be attributed, according to this same traveler, partly to the belief held by most Negroes that demons and spirits are white, and partly to their thinking it a sign of ill-health (Darwin, 1989, p.330).

This passage relates to what Pratthas called auto ethnographic text, or the description that the colonized makes of himself based on other social representations that have been made about him. It is a characterization that works as a response to other images through the appropriation of another - especially a hegemonic - language.

Darwin's discourse, similar to that of Tristán and Cané, reveals an ambivalent dynamic in the modes of representation by switching the tone of his discursive lines into an anti-slavery rhetoric. In The Descent of Man he claims that, 
Slavery, although in some ways beneficial in ancient times, is a great crime; yet it was not so regarded until quite recently, even by the most civilized nations. And this was especially the case because the slaves belong in general to a race different from that of their masters (Darwin, 1871, p.180).

It is highly revealing that Darwin's pro-abolitionist rhetoric is marked by various strategies to depict the "Other". In a letter to Mr. Wentworth Higginson, dated February $27^{\text {th }}, 1873$, he states "I always thought well of the Negroes, from the little of which I have seen of them; I have been delighted to have my vague impressions confirmed, and their characters and mental powers so ably discussed" (Darwin, 1873). In some excerpts one can see some paternalism towards the treatment of slaves and their conditions of suffering. In other instances, he may use other strategies such as their infantilism, naivety or stupidity, hospitality, or their inability to intervene in certain affairs. When talking about the man of the post-house in Argentina, for example, he admits that, "I did not anywhere meet a more civil and obliging man than this Negro; it was therefore the more painful to see that he would not sit down and eat with us" (Darwin, 1839, p. 68). In this case, hospitality and naivety are used as anti-conquest strategies to characterize the black man's behavior.
Darwin and his crew must have been shocked when they realized that the posta man would not sit down and eat with them. Within the enlightened western mindset, this attitude turns out to be strange or "abnormal". Regarding this, Hall observes that,

It was part of the natural order that white men should sit and slaves should stand; that white women rode and slave men ran after them shading them from the Louisiana sun with an umbrella; that white overseers should inspect slave women like prize animals, or punish runaway slaves with casual forms of torture (like branding them or urinating in their mouths), and that fugitives should kneel to receive their punishment (Hall, 1997, p.244).

David Spurr's explains that "the rational discourse of Western knowledge opposes reason to madness and truth to falsehood. It organizes the universe into disciplines which refuse the eccentric, the abnormal and the monstrous" (Spurr, 1993, p.62). This idea can be useful here. Although Darwin considers the man to be civil and obliging, this attitude seems not to be normal or in line with the "civilized" European cultural patterns to which he is accustomed. Although, the courtesy and helpfulness of the black man are highlighted in this passage, it could be that Darwin wants him to be part of his world, or perhaps it may be a way to strategically associate with him in order to more easily impose on him the customs of European culture.

This scene is also appropriate for what Franz Fanon has termed dimensions of the black man, or the way blacks interact with whites, which is not the same as when interacting with another person of the same race. For Fanon, because of colonial reasons:

The black man has two dimensions. One with his fellows, the other with the white man. A Negro behaves differently with a white man and with another Negro. That this self-division is a direct result of colonial subjugation is beyond question (Fanon, 1960, p.17).

Although it is evident that Darwin praises the virtues of the African man, he also chooses to represent him as being devoid of the social habits of "civilized" Europeans. According to this Eurocentric view, he is therefore, marked by exclusion: the absence of certain European values. It would follow that locals who imitate travelers would be looked upon favorably, whereas those who do not, would be frowned upon. Fanon's arguments explain this condition in a more emphatic way: "the colonized is elevated above his jungle status in proportion to his adoption of the mother country's cultural standards. He beco-

1 Term coined by Pratt meaning persons traveled to or (on) by a traveler. It is the receptor of travel. 
mes whiter as he renounces his blackness, his jungle" (Fanon, 1969, p.18).

Clearly, the black man's attitude calls into question Darwin's principle of authority, because authority and power are conferred by those who abide by them. This pointing out of cultural differences between the traveler and the travelee $^{1}$ also highlights the notion of the savage as the other; that is, as the antipode of the values of the civilized man.

Alfred Schutz has carefully examined the critical social and cultural relationship of the outsider with the members of the endogroup. He stresses the fact that, upon the encounter with the private codes of the target group, the outsider finds himself confronted by a frontier issue: he no longer has a status and must negotiate his position and his own cultural patterns. He will have to face basic discrepancies on perspectives and the handling of situations, which might be a cause for dismemberment in the profiles of meaningfulness (Schutz, 2003, p.102). How can one reconcile this ambivalent position? The discrepancy and the handling of the situation which Darwin experienced, might not only have caused him to swing between alienation and familiarity, but also allowed room for the travelee to question his or her own role in the relationship with a nonmember of their group. This does not, however, seem to have been the case since, according to what can be perceived in the text, there is no explicit reaction from the man towards Darwin's request. Intentionally or unintentionally, what is muted in the narration is the black man's reaction since he has no voice in the text. This silencing might suggest the assumption that non-European cultures need to catch up with the enlightened cultural patterns of the West.

\section{An invisible and homo- geneous collectivity}

As far as Humboldt's travel rhetoric is concerned, his point of departure on black issues rests upon a discourse based on humanitarian ideas. His discursive position allows for the articulation of an ideological project, which stems from a liberal and progressive mindset. But there is also something lacking in his narrative: consistency in the representation of the "Otherness". It is worth asking what could be the role played by the travelees in Humboldt's accounts? Do they have voices or have they been silenced as seen in the previous examples? Unlike Cané and Tristán, Humboldt needs some "helping hands" in the accomplishment of his scientific mission who mainly consist of indigenous and black local people who were knowledgeable about the territory, the fauna and the flora being studied. Some of these people would be guides, oarsmen or slaves who carried him and his crew on their backs enabling the success of their strenuous research missions.

Humboldt advocates for more humane laws concerning the treatment of slaves by their own masters and criticizes the current system of laws that were supposed to protect the slaves. He criticizes a royal decree that allowed for slaves to have recourse to a magistrate in order to enjoin the master to be more equitable, but which Humboldt considered illusory: "How can a slave, whipped, exhausted by hunger and excess of labour find means to appear before a magistrate? And if he did reach him, how would he be defended against a powerful master who calls upon the hired accomplices of his severities as witnesses?" (Humboldt, 1852, p.278). Humboldt seems to contradict popular ideas claiming that without slaves, there would be no be colonies, by citing a local declaration by a city council in the West Indies addressed to the Crown: "we declare, on the contrary, that without slaves, and even without blacks, colonies might have existed, and that the whole difference would have been comprised in more or less

2 Durante la época de la colonia, así se denominaba a los descendientes del cruce racial entre nativos americanos y franceses o escoceses, especialmente en las tierras de Norteamérica. 
profit by the more or less rapid increase of the products" (Humboldt, 1852, p. 280).

To illustrate the complexity of the representation of human relations in his texts it is interesting to note that, although these people, are useful in guiding Humboldt's expedition through jungles and mountains, they are scarcely identified either textually or visually. They seem to have no particular name and their traditions, customs, and knowledge are put aside as secondary to the narration. No wonder the author finds the combination of races to be a disturbing phenomenon:

This strange mixture of Indians, whites, negroes, metis, ${ }^{2}$ mulattoes and zambos, appears accompanied with all the perils which the heat and disorder of the passions can engender, at such critical periods, when society, shaken to its very foundations, begins a new era (Humboldt, 1852, p. 267).

The most urgent goals of colonial legislation, for him, should be the enactment of laws that,

Prohibit the degrading custom of marking the negroes with a hot iron, grant liberty to every slave who has served fifteen years, to every negress who has reared four or five children; set them free on the condition of working certain number of days for the profit of the plantation (Humboldt, 1852, p.267).

This paternalistic and ambiguous view regarding the situation of blacks is reinforced by the description and representation of these communities as exemplified in his encounter with some black sailors on the coast of South America: "These people fatigued the travelers with idle questions about their books and instruments and tried to frighten them with stories of boas, vipers and jaguars" (Humboldt, 1869, p.267).

The feeling of being threatened by the other and the fear of his expedition about the black race is also highlighted:

The travelers were going ashore to gather plants by moonlight when there issued from the thicket a young Negro loaded with fetters and armed with a cutlass. He urged them to disembark on a beach covered with large rbizophorae among which the sea did not break and offered to conduct them to the interior of the island of Baru if they would give him some clothes; but his cunning and savage air, his repeated inquiries as to their being Spaniards, and the unintelligible words addressed to his companions, who were concealed among the trees, excited their suspicions and induced them to return on board. These blacks were probably maroon negroes who had escaped from prison. The appearance of a naked man, wandering on an uninhabited shore and unable to rid himself of the chains fastened round his neck and arm, left a painful impression on the travelers; but the sailors felt so little sympathy with these miserable creatures that they wished to return and seize the fugitives in order to sell them at Carthagena (Humboldt, 1869, p.270).

This paper attempted to explore the racialized regimes of representation carried out by postcolonial travelers who undoubtedly were influenced by a prior history of colonization. Travel genre texts were chosen because they constitute a propitious space to analyze practices of representation and, at the same time, these texts provide a critical realm to revisit the diasporic black experience. A transparent racism permeates these travel narratives.

Blacks portrayed in these accounts serve as a "screen" on which society projects its fears, anxieties and threats. Material wealth and moral goodness were core values of the imperial enterprise and were markers of Western civilization. For Tristán, Europe, especially France and England, are the sources of progress and the countries Latin Americans should imitate. Darwin is proud of England for campaigning to stop other countries in using slaves. Humboldt praises North American and European ideals. Similarly, for Miguel Cané, Edenic Europe and the United States are undeniable homes of order and freedom (Cané, 2005, p. 83). These four travelers and authors concur that slavery is an aberration and, in their opinion, South American cou- 
ntries should be inspired by liberal ideas of emancipation. Nevertheless, the shifts and internal inconsistencies of their discourses regarding afrodescendants reveal the various social symptoms of the communities of which they were a part.

In addition, it is important to look beyond the traveler / travelee processes and consider other factors that play a part in these relationships such as regulatory state practices, institutions, or the specific historical moment, such as, for instance, the impact of the boom of pseudo-scientific ideologies, the decline of colonial empires such as Spain and the emergence of new ones like the United States of America. Depending on these circumstances, travelers choose to foreground things while others are marginalized in the narration. Do travelers freely choose to do so or are they forced by these circumstances? The answer will probably never be known.
But what can be determined is that historical transitions may alter the way people see the world and then write; therefore, these transitions may allow for an aesthetic manipulation of the locals in the narrative. What is more important for this study is that which is not explicitly stated; what is lacking here are not only the voices of the Africans and afrodescendants, but also their customs, traditions and culture which are invisibilized and, when, rarely, they are mentioned in the texts, they are mocked, degraded or underestimated. It is worthwhile noting that when two cultures come into contact, there is an effect left on each one of them or on both like when Cané witnessed the lack of inhibitions of the blacks as they celebrated the bamboula dance, he was actually witnessing a "culture of freedom and lack of inhibition".

It follows that although some of the blacks still depended on whites, they were not fully subjected to cultural restrictions which were rife in the "civilized" world. In spite of the fact that the white society of the time tried to make blacks "invisible", they fought against being rendered "invisible" because of their outsized and jubilant celebrations and dances. And even though they had no political freedom, they still had expressionistic freedom and that is how they showed they were alive and they were valuable individuals.

Further research is needed on this interesting subject. Studying the representational practices in these narratives is crucial because they will help to explain and partially show how many artistic and literary representations of difference nurtured the imaginary of other popular manifestations, as seen in novels, theater, visual art and other modes of expressions.

\section{References}

Cané, M. (2005). En viaje por Colombia y Venezuela. Caracas: Fundación Biblioteca Ayacucho.

Clifford, J. (1997). Routes: Travel and Translation in the late Twentieth Century. Cambridge: Harvard University Press.

Darwin, C. (1978).The Voyage of the Beagle. New York: Weathervane Books.

Darwin, C. (1989). The Descent of Man. London : William Pickering.

Darwin online. (s.f.). Recuperado el 21 de mayo de 2014 de http:/ / darwin-online.org.uk/contents.html.

Ellingson, T. (2001). The Myth of the Noble Savage. Los Angeles: University of California Press. 
Frantz, F. (1960). Black Skin, White Masks. New York: Grove Press.

Hall, S. (1997). Representation: Cultural Representations and Signifying Practices. London: Sage Publications, Inc.

Humboldt, A., Bonpland, A.(1852). Personal Narrative of Travels to the Equinoctial Regions during the years 1799-1804. London: Henry G. Bohn.

Humboldt, A. (1869).The Travels and Researches of Alexander Von Humboldt. New York: Harper \& Brothers.

Pratt, M. L. (1992). Imperial Eyes: Travel Writing and Transculturation. London: Routledge.

Phillion, J. (2006). Narrative Inquiry in a Multicultural Landscape. Wichita: IAP Publications.

Rama, A. (1984). La ciudad letrada. Hanover: Ediciones del Norte.

Said, E. (1979). Orientalism. New York: Vintage Books.

Schultz, A. (2003). Estudios sobre teoría social. Madrid: Amorrortu Editores España SL.

Seixo, M. (2000). Travel Writing and Cultural Memory. Amsterdam: Rodopi B.V.

Spurr, D. (1993).The Rhetoric of Empire: Colonial Discourse in Journalism, Travel Writing, and Imperial Administration. Durham: Duke University Press.

Thompson, C. (2011). Travel Writing. Abingdon: Routledge.

Todorov, T.(1992).The Conquest of America. New York: Harper Perennial Publishers.

Tristán, F. (2003). Peregrinaciones de una paria. Lima: Fondo Editorial.

Young, R. (2003). Postcolonialism. Oxford University Press, New York: 2003. 